\title{
Oil in the New World Order
}

Edited by Kate Gillespie and Clement M. Henry. University Press of Florida, 1995.

This readable and informative book discusses recent and expected future developments in the oil industry. It is a compendium of ten articles by academics and industry experts.

In the introduction, the editors argue that the international oil industry is a peculiarly volatile industry. Oil prices are very sensitive to crises in the Middle East, where two-thirds of the world's oil reserves are located, where half of the intemationally traded oil is produced, and where the cost of production is the lowest in the world. They maintain that, due to the inherent inelasticity of both demand and supply of crude oil and high price volatility, markets have never worked for oil industry efficiently. Consequently, there has always been some sort of market order. The editors provide a survey of the different orders that prevailed in the past, such as John D. Rockefeller's monopoly through the Standard Oil Trust, the dominance of the vertically integrated Seven Sisters, and 
OPEC. The current oil order, according to the authors, is the Saudi-American regime, which emerged after the Iraqi invasion of Kuwait and the subsequent Desert Storm. This regime, which combines huge Saudi oil production capacity with American military might, has replaced OPEC. The editors do not expect it to last long, because the new world order following the collapse of the Soviet Union may give rise to a new oil regime independent of the Saudi-American regime: the Commonwealth of Independent States has a potential of huge oil reserves that can be produced at a low cost.

The introduction is followed by Part I, which comprises three articles on oilrelated global issues from different economic and financial perspectives. The authors of the first article argue that, after a period of vertical disintegration due to the nationalization of oil concessions and OPEC's emergence, the oil industry will move again toward more integration. This time, the initiative for vertical integration will be taken by the oil-producing countries through their national oil companies. The motivation for vertical integration is the desire of oil producing countries to diversify by investing more in downstream operations (i.e., refining) and to consolidate their market shares. Besides, such important oil producing countries as Algeria, Iran, and Iraq lack the financial resources needed for further development of their oil industry. Thus, entering into such arrangements as joint ventures with multinational oil companies is a viable alternative.

The authors of the second article assert that the objectives of diversification and reliable sales outlets can be achieved by using forward markets instruments, rather than pursuing costly vertical integration. However, they point out that integration through financial markets requires futures contracts of a longer term than the current futures contract, which is limited to three years. The third article discusses the regionalization of oil markets as another possible future for oil. The authors argue that major oil importing countries would prefer to develop regional trading with high-cost producers than to depend on the unstable lowcost producers of the Middle East. This regionalization would be based on mutual economic and political interests between proximate exporters and importers. They envision three trading blocs: North America and the oil exporting countries of northern South America; Europe, Russia, the Central Asian Republics, North Africa, and West Africa; and Japan, South East Asia, China, and the Russian Far East.

Part II provides case studies on Algeria and Kuwait. The case studies show two different approaches to the utilization of the huge financial resources from oil exports in the 1970s and the early 1980s. Algeria pursued a policy of independent development and industrialization, whereas Kuwait pursued vertical integration by investing in downstream operations in Europe. For various economic and political reasons, Algeria's industrialization policy has failed to achieve the envisioned results. Faced by the consequences of failure of its development plans, Algeria is reversing its policy and moving toward joint ventures in the oil sector and opening up for foreign direct investments. Kuwait's overseas investment policies, despite domestic criticism and corruption allegations, proved to be a success, particularly during the Iraqi invasion. The proceeds from these investments helped support the Kuwait government in exile.

Part III discusses the challenges in the former Soviet Union. Russia has the potential of finding more oil reserves and increasing significantly the production of existing oil fields. In order to realize its potential, Russia needs foreign investments, technology, and managerial skills. Therefore, it has undertaken policy 
and legal reforms in the oil sector that are intended to facilitate joint ventures and other forms of foreign direct investments. The second article analyzes how the republics of Central Asia, through their potential reserves and low production costs, can become a great challenge to the Middle East's grip on the world oil market. However, political instability and ethnic rivalry might impede the realization of their potential.

Part IV contains three-well-discussed articles about the Middle East, the most critical and problematic region as far as oil is concerned. The first article deals with oil policy. The author argues that Iran has become less revolutionary and more pragmatic in its oil policy. Iran is changing its production, pricing, and marketing policies to insure price stability and revenue predictability and is also stressing the principle of reciprocal supply-demand securities, which means security of supply to consumers and security of demand to producers. Another important development in its oil policy is opening the door for joint ventures with international oil companies. Driving this policy change is competition for market share and the need for capital and technology to expand oil production capacity.

In "Progress Postponed: Iraqi Oil Policy, Past, Present, and Future," the author looks at the development of the Iraqi oil industry and how the achievements were almost aborted by Desert Storm. An interesting outcome of this war, as the author indicates, is that the United Nations has become an important player in the oil market through its control of Iraq's oil exports. According to the author's analysis, the prospects of Iraq's return to the international oil market in the near future are not good. The final article in part IV provides a good discussion of oil politics in the Gulf Cooperation Council (GCC) states. The author argues that the GCC states, which have small populations and few other natural resources, are pursuing a long-term policy of keeping oil prices low to discourage the development of alternative sources of energy among oil importing countries. However, this objective may conflict with their short-term revenue needs. It is probable that short-term revenue needs dictate a different oil policy. Current revenue needs are the product of massive spending that followed the high oil revenues in the 1970s and the early 1980s. Most of the development and social welfare programs were established during that period. Thus, high oil revenue is very critical in the short term to meet high public expectations and to insure social and political stability. Saudi Arabia and Kuwait, according to the author, are the only GCC countries, at least in the short run, whose account income is insufficient to meet current and projected revenue needs. The author asserts that, due to the high degree of social cohesion and traditional public participation through bay'ah, the GCC states are relatively stable and the rulers enjoy public support. Thus, radical political changes are not likely to occur in the near future. Meanwhile, the Saudi- American oil regime will persist.

An appendix to this compendium of articles provides illuminating managerial perspectives on different interesting and relevant topics. A major strength is the accompanying comprehensive coverage of all economic and political issues of oil in the new world order. Most of the analyses presented are sound and interesting.

Anas H. Hamed Department of Applied Economics Grambling State University Grambling, Louisiana 